\title{
A Closely-Held Companies ACt FOR NEW ZEALAND
}

\author{
Matthew Farrington*
}

This paper examines the law relating to closely-held companies. It concludes that the Companies Act's regulatory requirements imposed on directors to ensure accountability to shareholders do not have any benefit where companies are closely-held. The costs arising from such regulatory requirements are therefore unjustified.

The paper therefore argues that New Zealand should adopt a new flexible and accessible statute designed to meet the needs of closely-held companies. This statute should be in addition to the existing Companies Act, and should be informed by comparative precedent. This paper argues that the key features of this statute should include removing the distinction between shareholders and directors. This in turn removes the need to impose regulatory requirements on directors in favour of shareholders. The other features relating to defining a closely-held company, limited liability, protections for creditors, and relations between "principals" are also considered in this paper. The net result is a simple, straightforward set of requirements suitable for closely-held companies in New Zealand, without onerous or unjustified compliance requirements.

\section{INTRODUCTION}

This paper examines the law relating to closely-held companies. The majority of companies in New Zealand are "closely-held". That is, the company's shareholders are also its directors - there is no separation of ownership and management. The best manner to regulate closely-held companies is therefore a particular issue for New Zealand.

The paper considers the provisions of the Companies Act 1993 and in particular its regulatory requirements. The paper endeavours to show how many of the regulatory requirements, designed to ensure the accountability of a company's directors to its shareholders, are inappropriate for closelyheld companies. There is no benefit from such requirements for closely-held companies, rendering compliance with such requirements an unjustified cost.

* Submitted as part of the LLM programme at Victoria University of Wellington. 
The paper therefore concludes that New Zealand's current law is inadequate to meet the needs of closely-held companies and proposes changes to the existing law. The paper argues that the issues would be best addressed by a new statute designed to meet the needs of closely-held companies. It considers the general principles that may inform the design of such a statute, and makes specific design recommendations for the new statute. In the tradition of the Law Commission's proposals for company law reform, ${ }^{1}$ the paper also sets out possible draft clauses for the new statute. The recommendations for reform are based on this paper's empirical findings and identified issues. The paper is also influenced by comparative international precedent, particularly that of South Africa ${ }^{2}$ and the United States. ${ }^{3}$

\section{CLOSELY-HELD COMPANIES IN NEW ZEALAND}

This section of the paper analyses the nature of companies in New Zealand. In particular, it focuses on the ownership structure of New Zealand companies to attempt to determine the proportion that are "closely-held". For the purposes of this paper, a company is considered "closelyheld" if its owners (shareholders) are involved in, or close to (for example, through family ties), the management of that company. ${ }^{4}$

\section{A Number of Closely-Held Companies}

There are no direct statistics available on the exact number of companies with shareholders involved in management. The Small Business Advisory Group however, considers that the "typical" small and medium-sized enterprise will "have the owner as the only person in a managerial position, and no board or formal governance arrangements". ${ }^{5}$ Referencing the figures for small and mediumsized businesses, some 96 per cent of New Zealand businesses fit within this category. ${ }^{6}$

1 New Zealand Law Commission Company Law: Reform and Restatement (NZLC R9, Wellington, 1989), paras 5-7 ["Law Commission Company Law Report"].

2 Close Corporations Act 1984 (ZA).

3 This paper uses the examples of the Wyoming Limited Liability Company Act, Wyo Stat title 17, chapter 15 (1977), and the National Conference of Commissioners on Uniform State Laws Uniform Limited Liability Company Act (National Conference of Commissioners on Uniform State Laws, Chicago, Illinois, 1996) http://www.nccusl.org (accessed 15 July 2006) [Uniform Limited Liability Company Act (1996)].

4 Other factors that may be considered in other contexts include the number of shareholders, lack of a market for the shares and even the geographical proximity and relationship of the shareholders with each other see Baruch Gitlin "When Is Corporation Close, or Closely-Held, Corporation Under Common or Statutory Law" (2003) 111 ALR 5th 207, § 2[a].

5 Small Business Advisory Group Small and Medium Businesses in New Zealand: Report of the Small Business Advisory Group 2004 (Ministry of Economic Development, Wellington, 2004) http://www.med.govt.nz (accessed 18 August 2006) 3-4. The criteria for small or medium enterprises are not settled. The New Zealand statistics referenced in this paper primarily rely on the number of full timeequivalent employees, with 5 or less representing a "small" business and 6 to 19 representing a "medium" business - see, in particular, Ministry of Economic Development SMEs in New Zealand: Structure and 
This reflects Companies Office statistics: ${ }^{7}$ New Zealand has over 431,000 limited liability companies registered under the Companies Act. Of these companies, 140,000 have only one shareholder (33 per cent of all companies), 186,000 have two shareholders (43 per cent) and 80,000 have three to five shareholders (18 per cent). In total, 408,000 companies (nearly 95 per cent) have five or fewer shareholders. The popularity of the limited liability company has undoubtedly been enhanced by matters such as a robust approach to limited liability, ${ }^{8}$ ease of incorporation, ${ }^{9}$ succession and family planning advantages, ${ }^{10}$ and the potential for income splitting and lack of tax disadvantages. ${ }^{11}$

While unification of ownership and management is not the same as a small number of shareholders in a company, there is some correlation between the number of shareholders and their involvement in management. In particular, it is necessary to have a relatively small number of shareholders to have them practicably involved in management (although this factor on its own is not sufficient to make a company closely-held). The number of shareholders therefore provides some guidance as to whether a company is closely-held or not. The exact number of shareholders beyond which it is not practicably possible for all shareholders to be involved in management is not settled in existing law. By any measure, however, it will be greater than five shareholders. Other New Zealand statutes that differentiate between different companies on the basis of number of shareholders without exception use a figure of at least five. ${ }^{12}$

Dynamics - 2006 (Ministry of Economic Development, Wellington, 2006) www.med.govt.nz (accessed 18 August 2006) 5-6.

6 SMEs in New Zealand - Structure and Dynamics - 2006, ibid, 6.

7 Companies Office Statistics (Obtained under Official Information Act 1982 Request to the Companies Office, Business Services Branch, Ministry of Economic Development). See also www.companies.govt.nz (accessed 18 August 2006). Figures have been rounded to the nearest thousand.

8 See Salomon v A Salomon \& Co Ltd [1897] AC 22 (HL) and Lord Cooke of Thorndon "A Real Thing" in A Borrowdale, D Rowe and L Taylor (eds) Company Law Writings: A New Zealand Collection (The Centre for Commercial and Corporate Law, Christchurch, 2002) 21.

9 To incorporate a company in New Zealand, a person is only required to complete a straightforward form and pay a fee - see Companies Act 1993, s 12 and Companies Act 1993 Regulations 1994, First Schedule, Form 1. This can be completed entirely on-line - see Companies Act 1993, s 360(4) and www.companies.govt.nz (accessed 18 August 2006). The fees are also very low - see Companies Act 1993 Regulations 1994, reg 5 and Second Schedule, Part 1.

10 See, for example, Maw v Maw [1981] 1 NZLR 25 (CA).

11 See, in particular, Income Tax Act 2004, s HG1 (relating to loss attributing qualifying companies).

12 See, for example, Takeovers Act 1993, s 2 definition of "specified company" and Takeovers Code, clause 3, definition of "code company", Financial Reporting Act 1993, s 6(g), Income Tax Act 2004, s HG1, and Close Corporations Act 1984 (ZA), s 2(1). 
The above figures cannot be considered conclusive as to the number of closely-held companies in New Zealand. Not necessarily all of the 96 per cent of businesses that are small or medium-sized will be closely-held, nor the 95 per cent of companies that have five or fewer shareholders. Some may have shareholders that are not involved in management; others may be subsidiaries of larger widely-held companies with professional independent directors. Nevertheless, this paper considers that it is fair to conclude from the figures that closely-held companies make up a significant number of New Zealand companies.

\section{B Other Information}

Two other matters arising from the empirical information are also worth briefly noting: synonymity and informality. These are both characteristics of closely-held companies that are relevant for the purposes of this paper.

\section{Synonymity}

By definition, the directors of a closely-held company will also be its shareholders. There is obviously an alignment of interests in this respect. This synonymity is, however, reinforced by several other matters apparent from the empirical information. In particular, the livelihoods of directors/shareholders will be largely synonymous with the fortunes of their companies. A significant majority of small and medium-sized businesses' capital is contributed by the individuals in control of the business. ${ }^{13}$ This is compounded by the use of personal guarantees for debt finance. While only one-quarter to one-third of small-and-medium businesses seek loans, ${ }^{14}$ the directors/shareholders of those that do will probably have to give a personal guarantee for the debts of the company (there is, however, some conflicting data on this point). ${ }^{15}$ Finally, the directors/shareholders will probably also be employed by the business. ${ }^{16}$ This means that the principal(s) may also be dependent on the company for their day-to-day income. The directors/shareholders' invested capital, the family home and other assets, and day-to-day income may all be at risk in the event of business failure.

13 See Statistics New Zealand Business Finance in New Zealand 2004) (Statistics New Zealand, Wellington, 2004) www.stats.govt.nz (accessed 18 August 2006) 24 and 70.

14 See ibid, 9 and 50.

15 See PricewaterhouseCoopers Bank Lending Practices to Small and Medium Sized Enterprises (Ministry of Economic Development, Wellington, 2003) www.med.govt.nz (accessed 18 August 2006) 29-31, and Small Business Advisory Group Small and Medium Businesses in New Zealand: Report of the Small Business Advisory Group 2004, above n 5, 3. Note, however, PricewaterhouseCoopers Bank Lending Practices to Small and Medium Sized Enterprises, 30, and Statistics New Zealand Business Finance in New Zealand 2004, above n 13, 30-31 and 78.

16 Small Business Advisory Group Small and Medium Businesses in New Zealand: Report of the Small Business Advisory Group 2004, above n 5, 3, and Ministry of Economic Development SMEs in New Zealand: Structure and Dynamics - 2006, above n 5, 6. 


\section{Informality}

The empirical evidence also tends to indicate that most closely-held companies operate informally, and do not strictly observe all regulatory requirements. ${ }^{17}$ This lack of formal compliance can occur in a number of ways. Matters may be neglected by accident or oversight, ${ }^{18}$ due to ignorance of the law or lack of capacity, ${ }^{19}$ failure to seek professional advice, ${ }^{20}$ or even by reckless or deliberate disregard of the legal requirements. ${ }^{21}$ In addition to non-compliance, "informal compliance" may also occur. For example, rather than attending to ongoing obligations as they are technically required, these obligations may be addressed in an end-of-year "wash-up" of legal requirements. ${ }^{22}$

\section{IMPLICATIONS}

\section{A Regulatory Requirements}

Company law imposes numerous regulatory requirements in an effort to prevent potential abuse of the corporate form. While some of these requirements fall on companies directly ${ }^{23}$ (and in some exceptional circumstances, shareholders), ${ }^{24}$ the majority of company regulation imposes requirements on directors, as the individuals with the power to control a company. ${ }^{25}$

17 Small Business Advisory Group Small and Medium Businesses in New Zealand: Report of the Small Business Advisory Group 2004, above n 5, 3-4. See, for example, Mason v Lewis (2006) 9 NZCLC 264,024, para 58 (CA) Judgment of the Court.

18 See, for example, Re Economy Service Ltd (alt cit Caddis v Roskam) (1997) 8 NZCLC 261,441 (HC).

19 See, for example, Hale v Registrar of Companies (28 September 2006) HC AK CRI-2005-404-241; CRI2005-404-237, in particular paras 7, 9 and 10 Potter J. See also David Goddard "Company Law Reforms Lessons from the New Zealand Experience" in A Borrowdale, D Rowe and L Taylor (eds) Company Law Writings: A New Zealand Collection, above n 8, 145, 166.

20 See, for example, Business New Zealand and KPMG Summary Report of the Business New Zealand-KPMG Compliance Cost Survey (Business New Zealand and KPMG, Wellington, 2005) www.businessnz.org.nz (accessed 18 August 2006), Summary Tables and Graphs, Table 47, and Small Business Advisory Group Small and Medium Businesses in New Zealand: Report of the Small Business Advisory Group 2004, above n 5, 3-4.

21 See, for example, Re Cellar House Ltd (In Liquidation) (alt cit Walker v Allen) (18 March 2004) HC NEL CP13/00, paras 133, 143, 180 and 209-211 Ellen France J, and Mason v Lewis, above n 17, para 58 Judgment of the Court.

22 Goddard "Company Law Reforms - Lessons from the New Zealand Experience", above n 19, 165.

23 For example, use of company name - see Companies Act 1993, s 25, in particular subs (5)(a).

24 See, for example, McCullagh v Gellert (alt cit Re Gellert Developments Ltd (In Liquidation)) (2002) 9 NZCLC 262,942 (HC).

25 Companies Act 1993, s 128. 
These regulatory requirements on directors take a number of forms, including:

(1) Imposing general duties on directors; ${ }^{26}$

(2) Substantive restrictions on certain actions; ${ }^{27}$

(3) Structural distribution of powers within a company; ${ }^{28}$ and

(4) Procedural requirements. ${ }^{29}$

Generally, such requirements may be described as being for the benefit of shareholders and creditors $^{30}$ - those in the position of relative vulnerability to abuse of the corporate form by directors. The interests of other stakeholders (for example, customers, employees, the environment and so on) are normally addressed outside company law in other specific legislation. ${ }^{31}$

In relation to shareholders, ${ }^{32}$ the regulatory requirements have a number of specific aims. First, they make directors accountable to shareholders for actions that may prejudice the position of shareholders. This includes both liability to make good wrongs suffered by shareholders ${ }^{33}$ and liability to account for personal benefits gained that have been denied to shareholders. ${ }^{34}$ Second,

26 See, for example, Companies Act 1993, ss 131-138.

27 For example, prohibiting distributions in breach of the solvency test and prohibiting entering transactions that cannot satisfy the solvency test - see Companies Act 1993, ss 4, 52, 108 and 137.

28 For example, reserving control of major transactions to shareholders - see Companies Act 1993, s 129.

29 For example, the assorted "disclosure" requirements that are considered immediately below - see below, $\mathrm{n}$ 36-39.

30 See Law Commission Company Law Report, above n 1, paras 19 and 23.

31 See, for example, Law Commission Company Law Report, above n 1, paras 17-19; L S Sealy "Directors' 'Wider' Responsibilities - Problems Conceptual, Practical and Procedural" (1987) 13 Monash U LR 164; R Baxt "Can the Law Relating to Directors' Duties be Reformed?" (1990) 10 C and SLJ 110, 114-115; and Australian Senate Standing Committee on Legal and Constitutional Affairs Company Directors' Duties (Australian Government Publishing Service, Canberra, 1989), paras 6.1 and following ["Cooney Report"].

32 The position of creditors is discussed below - see Part V C Creditors, Limited Liability and Regulatory Requirements.

33 For example, supervising the share register (see Companies Act 1993, ss 90 and 169(3)). This can be considered a "negative" duty - directors must not act against the interests of shareholders.

34 For example, requiring directors to act in the best interests of the company (see Companies Act 1993, s 131) and restrictions on self-interested transactions (see Companies Act 1993, ss 139-140). This can be considered a "positive" duty - directors must act in the interests of shareholders. See, for example, Bridge $v$ M B Cook \& Co Ltd (16 September 1999) HC CHCH CP53/99. 
they attempt to ensure shareholders ${ }^{35}$ are informed of relevant matters through assorted "disclosure" requirements. ${ }^{36}$ Disclosure further promotes accountability by ensuring that shareholders can make informed decisions, ${ }^{37}$ and by encouraging good directorial decision making ${ }^{38}$ and business disciplines. ${ }^{39}$ Finally, the regulatory requirements create a basis for liability. ${ }^{40}$

The problem with this is, of course, that such requirements are a total nonsense for closely-held companies. There is no accountability of directors to shareholders where the directors are also the shareholders. Making good any wrongs suffered would amount to no more than a "money-goround." Similarly, disclosure of information already known would be a "paper-go-round" of records given and received by, and for the nominal benefit of, the same set of people. Even the good decision making and business discipline rationales are undermined by the practicalities of the reporting requirements, particularly the significant delay in preparation. ${ }^{41}$ Even if a director were to breach one of the requirements of the Companies Act, a shareholder-plaintiff is hardly likely to take action against him/herself as director-defendant. ${ }^{42}$

Moreover, there is no need for such accountability. Directors do not need to be provided with an incentive to act in the best interests of the shareholders. Self-interest and synonymity will take care

35 The Law Commission identified shareholders as the primary audience for disclosure by companies and directors - see Law Commission Company Law Report, above n 1, paras 192, 494 and 610-623. See also Hale $v$ Registrar of Companies, above n 19, para 25 Potter J.

36 "Disclosure" includes the assorted record-keeping, certification and notice requirements - see, for example Companies Act 1993, ss 41-81, 129, 140, 160, 189, 194, 208, 209 and 211 and Third Schedule, clause 6, and Financial Reporting Act 1993, ss 10-14.

37 See Law Commission Company Law Report, above n 1, paras 198-199.

38 For example, through the theory that "good processes are more likely to lead to good decisions" - see Goddard "Company Law Reforms - Lessons from the New Zealand Experience", above n 19, 155-156; England and Wales Law Commission and the Scottish Law Commission Company Directors: Regulating Conflicts of Interests and Formulating a Statement of Duties (LAW COM No 261; SCOT LAW COM No 173, London, 1999) www.lawcom.gov.uk (accessed 20 July 2006) paras 4.53-4.61; Simon Deakin and Alan Hughes Directors' Duties: Empirical Findings (Report to the England and Wales Law Commission and the Scottish Law Commission, ESRC Centre for Business Research, University of Cambridge, 1999) Table 17; and Law Commission Company Law Report, above n 1, paras 494, 520-522 and clause 107.

39 See, for example, Law Commission Company Law Report, ibid, para 601 and clause 156; Mason v Lewis, above n 17, paras 85-87 Judgment of the Court; and Hale v Registrar of Companies, above n 19, para 25 Potter J.

40 See Companies Act 1993, Part IX.

41 See Financial Reporting Act 1993, in particular, section 10(2).

42 See also R Dugan "Closely Held Companies under the Draft Companies Act" (1990) 20 VUWLR 161, 172173. 
of that. ${ }^{43}$ The regulatory requirements imposed by the Companies Act are therefore inappropriate for closely-held companies.

\section{B Costs of the Requirements}

The regulatory requirements of the Companies Act have potentially-significant compliance costs. The technical nature of company law means that closely-held companies and/or their directors are likely to expend significant costs determining their exact legal obligations. ${ }^{44}$ If they choose to do it themselves, ${ }^{45}$ this will take the form of time and effort reading the Act or textbooks. Alternatively, it may take the form of the cost of professional advice.

There are no reliable quantitative assessments of the level of compliance costs. A recent survey does, however, provide some guidance in this area. ${ }^{46}$ Businesses were asked to rank their compliance cost "priorities". The joint requirements of the Companies Act, Takeovers Act 1993 and Securities Act 1978 were ranked the seventh top "priority". ${ }^{47}$ The Companies Act aspect of this is most significant, given that virtually no small businesses have to comply with the Takeovers Act ${ }^{48}$ or Securities Act. ${ }^{49}$

In addition to costs, regulatory requirements also carry the potential for liability "traps". There does not appear to be any particular incentive for directors of closely-held companies to comply with the assorted regulatory requirements. There is neither any benefit, nor any particular likelihood of shareholder enforcement. ${ }^{50}$ In fact, many directors of closely-held companies may not even be

43 See above, Part II A $11 \quad$ Synonymity.

44 The Law Commission proposed a "codified" reference point of directors' disclosure obligations - see Law Commission Company Law Report, above n 1, clause 179. This clause did not find its way into the Companies Act 1993. As to accessibility of statute law, see also Rt Hon Sir Geoffrey Palmer, President, Law Commission "Law Reform and the Law Commission after 20 Years - We Need to Try a Little Harder" (Address to the New Zealand Centre for Public Law, Victoria University of Wellington, 30 March 2006) Speech Notes, paras 34 and following.

45 As is apparently the case for most smaller businesses - see above, Part 2 Informality.

46 Business New Zealand and KPMG Summary Report of the Business New Zealand-KPMG Compliance Cost Survey, above n 20.

47 That is, these Acts impose the seventh highest compliance costs for business - see ibid, 5 and 7 and Summary Tables and Graphs, Table 14.

48 The Takeovers Act 1993 only applies to listed and formerly-listed companies, and companies with 50 or more shareholders - see Takeovers Act 1993, s 2 definition of "specified company" and Takeovers Code, clause 3 definition of "code company".

49 The Securities Act 1978 only applies to issuers of securities to the public - see Securities Act 1978, s 3 and Part 2. While closely-held companies could issue securities to the public (particularly debt and participatory securities), the majority of closely-held companies very probably do not.

50 See above, Part III A Regulatory Requirements. 
aware of the assorted requirements. ${ }^{51}$ There are, however, a number of liability "traps" that may cause significant difficulties for unwary directors of closely-held companies.

In terms of civil actions, if a company were to go into liquidation, its directors may find themselves pursued by the liquidator of the company for any failure to comply with the regulatory requirements. ${ }^{52}$ Directors may also be required to make a contribution to the company if they have been guilty of negligence or default in complying with the Companies Act requirements, particularly the accounting requirements. ${ }^{53}$ Finally, state-enforced criminal sanctions may also be imposed for failure to comply with assorted requirements, ${ }^{54}$ although prosecutorial discretion would probably mean that breaches of the law that do not cause any harm would not be prosecuted.

It should be re-emphasised, however, that the Companies Act regulatory requirements do not appear to have any significant benefit in the case of closely-held companies. No matter how small the costs, they will never be justifiable on a cost-benefit analysis if the benefit is zero. This paper therefore argues that the requirements are an unjustified burden on closely-held companies.

\section{Concessions to Closely-Held Companies}

The inappropriateness of certain regulatory requirements in the case of closely-held companies ${ }^{55}$ was recognised by the Law Commission. As a result of the "excessive formalities on the day-to-day operation of small (and, in particular, one-shareholder) companies",56 the Law Commission proposed introducing a new section to the then-Companies Bill that would permit

51 See, in particular, Small Business Advisory Group Small and Medium Businesses in New Zealand: Report of the Small Business Advisory Group 2004, above n 5, 3-4, and above, Part 2 Informality. See also, for example, Mason v Lewis, above n 17, para 58 Judgment of the Court.

52 See Companies Act 1993, s 161 and, for example, McCullagh v Gellert, above n 24; Crichton v Amaru (2001) 9 NZCLC 262,549 (HC); Kiwibilt Engineering Ltd (In Liquidation) v Pavlovich [2004] DCR 193; and Macfarlane v Barlow (1997) 8 NZCLC 261,470 (HC) (note, however, that this latter case was brought by a minority shareholder not involved in management of the company, rather than a liquidator. The company does therefore not satisfy this paper's definition of "closely-held").

53 Companies Act 1993, ss 300 and 301. See, for example, Mason v Lewis, above n 17; Re Cellar House Ltd (In Liquidation), above n 21; and Re Hilltop Group Ltd (In Liquidation) (alt cit Lawrence v Jacobsen) (2001) 9 NZCLC 262,477 (HC).

54 For the list of criminal sanctions in the Companies Act (including penalties), see Companies Act 1993, ss 373-374.

55 While such measures are not necessarily limited to any particular sort of company, the practicalities of seeking - and obtaining - unanimous shareholder agreement mean that it is only likely to be used where the company is closely-held. Such opt-outs will presumably only occur where it is in the interests of shareholders to do so.

56 New Zealand Law Commission Company Law: Transition and Revision (NZLC R16, Wellington, 1990) para 45. 
shareholders to effectively opt-out of these formalities. ${ }^{57}$ In the Law Commission's view, shareholders should be entitled to waive matters for their benefit if they so desire. ${ }^{58}$ The Companies Act was eventually enacted with such opt-out provisions. ${ }^{59}$ There are, however, problems with these concessions as enacted. The net result of these issues is to undermine much of the greater flexibility anticipated by the Law Commission. ${ }^{60}$

Putting aside the obvious additional compliance burdens associated with an opt-out rather than opt-in mechanism, the first issue is that not all regulatory requirements are subject to shareholder opt-out. The majority of the disclosure requirements, for example, fall into this category. ${ }^{61}$ Closelyheld companies must therefore comply with these regulatory requirements, even though they are a "paper-go-round" without benefit.

Second, even where shareholders are able to opt-out, different sections require different procedural formalities in order to opt-out. ${ }^{62}$ There is no common, simple framework for closelyheld companies to address these assorted matters. This has resulted in a confusing array of differing provisions that closely-held companies must carefully consider, with ensuing compliance costs. One matter in this regard that may particularly frustrate shareholders is the inability to opt-out of some matters permanently, either by incorporating a permanent opt-out in the company's constitution or

57 New Zealand Law Commission Company Law: Transition and Revision, above n 56, para 45 and clause 78A. These comments were made in the Law Commission's follow-up report on company law following criticisms made of the initial report's rather limited concessions to closely-held companies. As to the criticism made of the initial draft, see New Zealand Law Commission Company Law Reform Supplementary Paper No 2 - Closely Held Companies - Unanimous Shareholder Agreements (31 January 1990) paras 4-5 (Obtained under Official Information Act 1982 Request to the Regulatory and Competition Policy Branch, Ministry of Economic Development) and R Dugan "Closely Held Companies under the Draft Companies Act", above n 42.

58 This is similar in concept to the doctrine of shareholder ratification - see Companies Act 1993, s 177. Note, however, the potential limitation in subs 177(3) - see also Morrison's Company Law (NZ) (Service 82, LexisNexis NZ, Wellington) paras 25.42-25.44 (updated July 2006) www.lexisnexis.co.nz (accessed 11 August 2006).

59 See, for example, Companies Act 1993, ss 107(1)-107(3), 196(2) and 211(3).

60 The Companies Act 1993 as enacted departs from the report of the Law Commission in a number of respects - see Goddard "Company Law Reforms - Lessons from the New Zealand Experience", above n 19, 156; Jenni McManus "Law Commission v Justice Department - Squabbling Officials Stall Company Law Reform" (25 October 1990) The Examiner New Zealand 5; and Bob Dey "Company Law - the Slow Job of Reform" (28 October 1990) The Dominion Wellington 23.

61 See above, Part III A Regulatory Requirements, in particular, nn 36-39.

62 For example, s 107 requires the opt-out agreement to be in writing. This is not apparently required for, for example, the agreement that certain matters not be included in the annual report - compare Companies Act 1993, s 107(4) with s 211(3). 
by passing "standing" unanimous resolutions. ${ }^{63}$ This compounds the problems of complying with the procedural formalities, as it is not possible for shareholders to turn their minds to the matter once and resolve it permanently. ${ }^{64}$

Finally, some of the procedural formalities of the Companies Act to effect an opt-out are problematic themselves. It is not clear what purpose these procedural formalities are intended to serve. The initial regulatory requirements which shareholders are seeking to opt-out of are to protect the interests of shareholders. Where shareholders seek to opt-out of regulatory requirements, however, there are no obvious candidates to be the "recipients" 65 of the "benefits" of the procedural requirements. Shareholders are "disclosing" matters to themselves. As for the initial regulatory requirements, the result is a "paper-go-round".

\section{PROPOSALS FOR REFORM: GENERAL PRINCIPLES}

The previous section of this paper outlined the issues arising from the Companies Act that affect closely-held companies. Given the prevalence of closely-held companies in New Zealand, this paper considers that the issues raised above are matters that should be addressed. This paper recommends adopting a new statute allowing businesses to register as closely-held companies. The requirements of such a statute would be tailored towards the specific needs of the up to 95 per cent of companies in New Zealand that are closely-held. This section of the paper considers some of the general principles that may inform the design of such a statute; the next section considers some specific features of the proposed statute.

\section{A The Need for Specific Legislation}

The first point to be made is the need for specific legislation. The Law Commission recommended that a single company law statute be adopted. The Commission considered that an appropriately-drafted statute could provide sufficient flexibility for every sort of company. ${ }^{66}$

This paper disagrees with the proposition that company law is infinitely "scale-able" in this fashion. This paper considers that the needs of widely- and closely-held companies are

63 For example, it is possible to opt-out "generally" from the requirements of s 107 until further notice, but the resolution not to appoint an auditor must be re-executed each year - compare Companies Act 1993, ss 107(5)(b) and 107(6) with Companies Act 1993 s 196(2).

64 See also Goddard "Company Law Reforms - Lessons from the New Zealand Experience", above n 19, 156158.

65 For example, Companies Act 1993, s 107(4) requires shareholder agreements under s 107 to be in writing. It is not necessary to give anyone a copy of this written agreement, however.

66 Law Commission Company Law Report, above n 1, paras 16-18, 66-72, 232-241 and 293-294 and New Zealand Law Commission Company Law Reform - Supplementary Paper No 2 - Closely Held Companies Unanimous Shareholder Agreements, above n 57, para 3(a). 
fundamentally different. In short, widely-held companies require mechanisms to ensure the directors are accountable to shareholders; closely-held companies do not.

While the Companies Act adequately caters for the needs of widely-held companies, ${ }^{67}$ it does not adequately address the situation faced by closely-held companies. Specific legislation that caters for the needs of closely-held companies is the best solution. ${ }^{68}$ Such new legislation would be in addition to the Companies Act. This paper does not advocate the repeal and replacement of the Companies Act, as it caters for the needs of widely-held companies.

\section{B Comparative Precedent}

There is a significant amount of comparative precedent to consider in formulating a new closely-held companies statute. Internationally, a number of jurisdictions have implemented statutes specifically designed for closely-held/private companies. ${ }^{69}$ Most relevant for New Zealand are the examples of the United States and South Africa. In the United States, the "limited liability company" is the fastest-growing business form in the United States. ${ }^{70}$ This popularity is due to a combination of flexibility, limited liability and favourable tax treatment. ${ }^{71}$ The broadly-comparable South African Close Corporations Act ${ }^{72}$ has met with similar success. ${ }^{73}$ These approaches have been described as a "hybrid" of company and partnership law. ${ }^{74}$ This "incorporated partnership"

67 Aspects of the Companies Act 1993 may be criticised even for widely-held companies. This is beyond the scope of this paper, however.

68 See, for example, Johan Henning "The Company Law Reform Bill, Small Businesses and Private Companies" (2006) 27 Comp Law 97, 97 and Goddard "Company Law Reforms - Lessons from the New Zealand Experience", above n 19, 163.

69 Particularly civil jurisdictions. The German Gesellschaft mit beschränkter Haftung or "GmbH" is often attributed the status of the "first" private companies statute. As to the actual comparability of United Statesstyle limited liability companies with the German GmbH, see Dominik Kallweit The US Limited Liability Company: A Role Model for German Company Law (LLM Research Paper, Victoria University of Wellington, 2003).

70 See, for example, Jeffrey K Vandervoort "Piercing the Veil of Limited Liability Companies: The Need for a Better Standard" (2004) 3 DePaul Bus \& Com LJ 51, 63. As to limited liability companies generally, see Kallweit, ibid, 4-6 and Fallany O Stover and Susan Pace Hamill "The LLC versus LLP Conundrum: Advice for Businesses Contemplating the Choice" (1999) 50 Ala L Rev 813, 813-821.

71 Uniform Limited Liability Company Act (1996), above n 3, prefatory note, 1.

72 Close Corporations Act 1984 (ZA).

73 See Rehana Cassim and Femida Cassim "The Reform of Corporate Law in South Africa" (2005) 16 ICCLR 411, 413. In particular, the article cites the fact that South Africa has approximately 880,000 actively registered close corporations, but only 300,000 private companies and 6,000 public companies.

74 Vandervoort "Piercing the Veil of Limited Liability Companies: The Need for a Better Standard", above $\mathrm{n}$ 70, 51. 
model has been put forward by a number of commentators recommending changes to company law in jurisdictions without such statutes. ${ }^{75}$

The United States and South African statutes have been successful in practice; New Zealand should carefully consider whether there are any compelling reasons for departing from proven success. ${ }^{76}$ This paper's proposals proceed on this basis. While the overall framework and some specific features are worth emulating, however, there are a number of changes that could usefully be made to this international precedent, particularly with the goal of simplification in mind. ${ }^{77}$ For example, the United States model is carefully structured so as to provide sufficient options to enable limited liability companies to take advantage of the particular tax situation in the United States. ${ }^{78}$ This would not be necessary in New Zealand, and so some of this complexity could be removed. This paper also considers other options for simplification.

From a domestic perspective it is worthwhile considering the provisions of partnership law. ${ }^{79}$ Partnerships are effectively closely-held businesses where the partners have both equity stakes ${ }^{80}$ and management rights ${ }^{81}$ in the business. Partnerships provide significant advantages in terms of flexibility, ${ }^{82}$ although do lack some of the features of company law, most notably, limited liability.

It is also important to consider the precedent of the existing Companies Act. Consistency with the existing law where possible would be advantageous: precedent and knowledge of existing concepts will make the new statute more readily understandable. Perhaps more importantly, the statute should not impose substantially more onerous obligations than the existing Companies Act. Otherwise, businesses would simply incorporate under the existing statute rather than the new closely-held companies statute.

75 See, for example, Andrew Hicks "Reforming the Law of Private Companies" (1995) 16 Comp Law 171, 176-177, Henning "The Company Law Reform Bill, Small Businesses and Private Companies", above n 68, 97, and Goddard "Company Law Reforms - Lessons from the New Zealand Experience", above n 19, 163.

76 Goddard "Company Law Reforms - Lessons from the New Zealand Experience", ibid, 165-166.

77 Ibid, 165-166.

78 Uniform Limited Liability Company Act (1996), above n 3, prefatory note, 1, and Stover and Pace Hamill "The LLC versus LLP Conundrum: Advice for Businesses Contemplating the Choice", above n 70, 815 and footnote 8.

79 See Partnerships Act 1908.

80 See Partnerships Act 1908, in particular s 27(a).

81 See Partnerships Act 1908, in particular s 27(e).

82 See Partnerships Act 1908, s 22. 


\section{Form of the New Legislation}

This paper further recommends that this new legislation be self-contained so far as possible. As discussed above, many closely-held companies operate informally and without professional advice. ${ }^{83}$ It is therefore necessary to state the law clearly and concisely to make it as accessible as possible to closely-held companies. ${ }^{84}$

This paper does not consider that the current approach of the Companies Act (allowing closelyheld companies to opt-out of particular provisions) is appropriate. Even if the assorted inconsistencies could be and were addressed, ${ }^{85}$ such an approach is not as accessible as a selfcontained statute. ${ }^{86}$ Currently, the entire statute must be considered and the applicable provisions determined by reference to the dis-applying section. An understanding of what one is opting out of is necessary. Further, there are many irrelevant provisions. Finally, additional procedural requirements are necessary to effect an opt-out. ${ }^{87}$ This paper therefore considers that accessibility would be better achieved either by means of a separate, stand-alone statute, or by adding a selfcontained part to the Companies Act.

\section{Flexibility}

The new closely-held companies statute should also provide sufficient flexibility to enable principals to conduct their own affairs as they desire. ${ }^{88}$ Excessive flexibility may, however, compromise the accessibility of the statute. ${ }^{89}$ The statute should therefore provide suitable "default" provisions that would apply unless the principals otherwise agree. ${ }^{90}$ This would provide guidance and accessibility for basic closely-held companies and their principals, while ensuring flexibility for specific purposes or more-advanced closely-held companies. Similarly, for certain requirements, it may be appropriate to provide general flexibility, but also to set out "safe-harbour" provisions. Safe-

83 See above, Part II B 2 Informality.

84 See Law Commission Company Law Report, above n 1, paras 121-126 and Palmer "Law Reform and the Law Commission after 20 Years - We Need to Try a Little Harder", above n 44, paras 34 and following.

85 See above, Part III C Concessions to Closely-Held Companies.

86 See also, for example, the comparative table of numbers of sections and pages in selected companies statutes in Goddard "Company Law Reforms - Lessons from the New Zealand Experience", above n 19, 164.

87 See also the Companies Bill 2005, no 190 (UK), and Henning "The Company Law Reform Bill, Small Businesses and Private Companies" above n 68, 97.

See Goddard "Company Law Reforms - Lessons from the New Zealand Experience", above n 19, 162.

89 See, for example, Partnerships Act 1908 and its failure to provide a "standard form" partnership agreement.

90 Goddard "Company Law Reforms - Lessons from the New Zealand Experience", above n 19, 167. 
harbour provisions are useful, as flexible legislation is necessarily drafted with a degree of generality. Safe-harbour provisions provide certainty that the law has been satisfied.

\section{PROPOSALS FOR REFORM: SPECIFIC FEATURES}

This section of the paper builds on the general principles considered in the previous section and recommends specific features of the new statute. In the tradition of the Law Commission's proposals for company law reform, ${ }^{91}$ the paper also sets out possible draft clauses for the new statute. ${ }^{92}$

The intent of this section is to set out the most important provisions of the new statute. It does not consider some of the detailed technical elements that would be necessary for the statute, for example, name ${ }^{93}$ and registration requirements, ${ }^{94}$ service of legal proceedings ${ }^{95}$ and the standard of knowledge required to impugn transactions. ${ }^{96}$ Finally, and perhaps critical to the success of the closely-held companies statute, the paper has not considered matters relating to taxation. These matters have not been able to be included within the scope of this paper.

\section{A No "Directors" and "Shareholders"}

The essential feature of a closely-held company is that its shareholders are also its directors. Recognising this fact would be the single most important element of the new statute. Most importantly, such an approach would clearly obviate the need to impose any regulatory requirements on "directors" to ensure accountability to "shareholders".

Rather than having "directors" and "shareholders", this paper instead proposes that the new statute refer to "principals" of closely-held companies. This encompasses the notion that principals both own and run closely-held companies. This approach is utilised in the United States ${ }^{97}$ and South

91 Law Commission Company Law Report, above n 1, paras 5-7.

92 The draft clauses are inserted as appropriate throughout the paper.

93 See, for example, Companies Act 1993, s 25; Close Corporations Act 1984 (ZA), s 22; Wyoming Limited Liability Company Act, Wyo Stat § 17-15-105(a) (1977) and Uniform Limited Liability Company Act (1996), s 105(a).

94 See, for example, Companies Act 1993, ss 13-14, Close Corporations Act 1984 (ZA), ss 12-13, Wyoming Limited Liability Company Act, Wyo Stat $\S \S ~ 17-15-106$ and 17-15-108 (1977), and Uniform Limited Liability Company Act (1996), above n 3, ss 206 and 208.

95 See, for example, Companies Act 1993, s 387 and Close Corporations Act 1984 (ZA), s 25.

96 See, for example, Companies Act 1993, s 19; Close Corporations Act 1984 (ZA), s 17 and Uniform Limited Liability Company Act (1996), above n 3, s 102.

97 See, for example, the Wyoming Limited Liability Company Act, Wyo Stat §§ 17-15-106, 17-15-107, and 17-15-113 - 17-15-116 (1977) and the Uniform Limited Liability Company Act (1996), above n 3, Article 4. Note, however, that these statutes also provide the option for Limited Liability Companies to have "managers" if they chose to do so (see Wyoming Limited Liability Company Act, Wyo Stat § 17-15-116 
Africa, ${ }^{98}$ both of which refer to "members" to encompass this concept. This paper uses "principals" to denote this member/shareholder/director concept.

\section{B Definition and Eligibility}

The prospect of distinguishing a closely-held company from an ordinary company caused the Law Commission some concern. ${ }^{99}$ This paper proposes, however, that the new closely-held companies statute be in addition to the Companies Act. Under this paper's approach, there is no need have a "bright-line" test to distinguish between the two sorts of companies. Whether to incorporate under the Companies Act or under the new closely-held companies statute would simply be a decision of the individual(s) concerned.

There does, however, need to be some eligibility criteria for closely-held companies. The proposed closely-held companies statute has been designed on the basis that all principals of a closely-held company would be involved in its management. This is not practicable where there are too many principals. ${ }^{100}$ South Africa has a limit of ten principals; ${ }^{101}$ this paper proposes the same number. It is acknowledged, however, that this is something of an arbitrary figure. In any event, however, the vast majority of businesses wishing to utilise a closely-held company structure will fall below this threshold. ${ }^{102}$

This paper also proposes that only natural persons be able to be principals. The same approach is adopted in South Africa. ${ }^{103}$ The intent of the statute is to address the issues associated with the Companies Act for closely-held companies. The needs of, and appropriate requirements for, subsidiaries of other companies are different to those of small owner-operated businesses. Such needs and requirements are outside the scope of this paper. A particular concern is the fact that principals exercise management power directly; another company is not able to do this under current

(1977), and Uniform Limited Liability Company Act (1996), s 404). This flexibility is primarily due to the United States tax provisions - see Uniform Limited Liability Company Act (1996), prefatory note, 1.

98 See Close Corporations Act 1984 (ZA), s 1(1), definition of "member" and Part IV.

99 New Zealand Law Commission Company Law Reform - Supplementary Paper No 2 - Closely Held Companies - Unanimous Shareholder Agreements, above n 57, para 3(b).

100 See also above, Part II A Number of Closely-Held Companies, in particular n 12.

101 Close Corporations Act 1984 (ZA), ss 2(1) and 28.

102 See above, Part II A Number of Closely-Held Companies.

103 See Close Corporations Act 1984 (ZA), s 29. 
New Zealand law. ${ }^{104}$ It is also worth noting that other legal avenues are available for matters such as venture capital investment. ${ }^{105}$ The new statute may therefore provide, for example:

Draft Clause: Eligibility for Membership of a Closely-Held Company

A Closely-Held Company must have at least one, but not more than ten, Principals, all of whom must be natural persons.

\section{Creditors, Limited Liability and Regulatory Requirements}

This paper criticises the regulatory requirements of the Companies Act in respect of shareholders of closely-held companies. The situation is quite different, however, for creditors and other contractual third-parties (collectively, "creditors").

Unlike director/shareholder interests, there is no synonymity of interests with creditors in the case of a closely-held company. ${ }^{106}$ Self-interest cannot be relied upon to prevent abuse. Limited liability means that creditors may not be able to practically recover against a debtor-company due to its impecuniosity, even where the company is clearly liable to the creditor. It is therefore necessary to impose some form of regulatory requirement to prevent abuse of the corporate form to the detriment of creditors. The costs of such requirements will be justified, so long as greater benefit flows to creditors.

There are a number of possible alternatives for such regulatory requirements. This section considers and rejects both the possibilities of removing limited liability, and imposing minimum capital requirements. Rather, the paper proposes imposing duties for the benefit of creditors. It also considers the form and standard of such duties, as well as some practical considerations.

\section{No limited liability}

Limited liability is typically considered as a key feature of company law. It encourages entrepreneurship and taking business risks without fear of recourse to the other assets of the shareholders. ${ }^{107}$ It is not, however, universally acclaimed. Objections have been raised both as a

104 The Companies Act 1993 requires directors to be natural persons - see Companies Act 1993, s 151(1).

105 Limited partnerships in particular are the preferred vehicle for the venture capital industry. New Zealand's limited partnership regime is currently under review - see Ministry of Economic Development A Limited Partnership Regime for New Zealand (Ministry of Economic Development, Wellington, 2005) www.med.govt.nz (accessed 18 August 2006) in particular para 5. There does not seem to be any reason why a closely-held company could not be the general partner in a limited partnership. This would allow equity investment in the business venture operated by the closely-held company while avoiding the difficulties described in this paragraph.

106 Although it is possible for the principal of a company/closely-held company to lend the company money. The principal would be the creditor of his/her own company.

107 See, for example, Companies Act 1993, long title, para (a); Rainham Chemical Works Ltd v Belvedere Fish Guano Co Ltd [1921] 2 AC 465, 475 (HL) Lord Buckmaster; New Zealand Law Commission Company 
matter of principle ${ }^{108}$ and practice. ${ }^{109}$ At least one commentator has proposed a closely-held business statute without limited liability. ${ }^{110}$ The essential rationales for this are that the majority of closely-held businesses do not want or need limited liability, ${ }^{111}$ and may abuse limited liability. ${ }^{112}$ Removing limited liability would also remove the potential for abuse of the company form. There would therefore be no need to impose regulatory requirements to counter this potential for abuse. The argument is that closely-held businesses would get greater benefits from the removal of limited liability than its retention. ${ }^{113}$

This ignores, however, the fact that it is possible to limit liability in other ways. It will, of course, be possible to limit liability by incorporating a company under the Companies Act rather than a closely-held company. It is also possible to limit liability contractually by including express terms to that effect with third parties. ${ }^{114}$ Contractual limitation or disclaimer of liability may even include some claims sounding in tort. ${ }^{115}$ It is also possible to implement a form of asset protection through family trusts ${ }^{116}$ and property relationship agreements. ${ }^{117}$ Moreover, regardless of one's normative views as to the appropriateness of limited liability, it must be accepted that limited liability is now a feature of the commercial environment. Limited liability does not appear to have

Law: A Discussion Paper (NZLC PP5, Wellington, 1987) paras 33 and 41 and Law Commission Company Law Report, above n 1, para 22(d).

108 See, for example, John Farrar "Frankenstein Incorporated or Fools' Parliament? Revisting the Concept of Corporation in Corporate Governance" in A Borrowdale, D Rowe and L Taylor (eds) Company Law Writings: A New Zealand Collection, above n 8, 59.

109 Andrew Hicks "Reforming the Law of Private Companies", above n 75, in particular 174 and following.

110 Ibid, in particular 176-177. The author also identifies some existing problems with partnership law that should be addressed - see 175-176.

111 Ibid, $175-176$.

112 Ibid, 174-175.

113 Ibid, 176-177.

114 As to the "standard form contract" model for company law, see, for example, New Zealand Law Commission Company Law: A Discussion Paper, above n 107, para 36, and Goddard "Company Law Reforms - Lessons from the New Zealand Experience", above n 19, 146. One intriguing possibility flowing from this standard form contract model is the prospect of providing for a Closely-Held Companies "Act" not as an Act of Parliament, but rather through common adoption of contractual terms - for example, making the "Act" publicly available, and allowing those that wish to "incorporate" under it to reference the terms of the "Act" contractually.

115 See, for example, Hedley Byrne \& Co Ltd v Heller \& Partners Ltd [1964] AC 465 (HL).

116 See, for example, Official Assignee $v$ Wilson [2006] 2 NZLR 841 (HC).

117 See, for example, Felton $v$ Johnson [2006] NZSC 31 (SC). Asset protection is not the same as limited liability, however; personal bankruptcy is a necessary precursor for asset protection to be necessary. 
been seriously challenged in any major review of company law. ${ }^{118}$ South Africa ${ }^{119}$ and the United States $^{120}$ both provide for limited liability for their closely-held companies. Finally, rejecting limited liability would be open to criticism on the basis that a nominally-enabling and facilitative statute does not adequately cater for the New Zealand business environment. ${ }^{121}$

Realistically, if a new closely-held companies statute were adopted without limited liability, parties that desire limited liability will either adopt contractual terms or incorporate under the Companies Act. The former will result in transactional inefficiency, while the latter will simply render the new statute redundant. It therefore seems appropriate that the new closely-held companies statute make provision for limitation of liability: ${ }^{122}$

Draft Clause: Limited Liability

The Principal(s) of a Closely-Held Company are not liable for the debts of the Closely-Held Company.

\section{Minimum capital requirements}

Maintaining limited liability means that it is necessary to resort to other avenues to ensure the corporate form does not lead to abuse of creditors. Minimum capital requirements are a traditional feature of company law. ${ }^{123}$ Such requirements theoretically prevent the formation of, or trading by, companies that run the risk of failure due to undercapitalisation.

Such requirements have significant problems, however, and were abolished in New Zealand in the current Companies Act. This paper considers that problems identified by the Law Commission with such requirements are compelling, and minimum capital requirements should not be introduced. ${ }^{124}$ Even if the Law Commission's reasons were not so compelling, the likely imposition of minimum capital requirements could not be required in isolation only for closely-held companies. Businesses would again simply chose to incorporate under the Companies Act instead. This paper

118 See, for example, Law Commission Company Law Report, above n 1; the Department of Trade and Industry Better Business Framework: Companies Bill (Department of Trade and Industry, London, 2006) www.dti.gov.uk (accessed 6 September 2006).

119 Close Corporations Act 1984 (ZA), s 2(3).

120 See, for example, Wyoming Limited Liability Company Act, Wyo Stat § 17-15-113 (1977) and Uniform Limited Liability Company Act (1996), above n 3, ss 201 and 303.

121 This is the same criticism levelled at the Companies Act 1993 by this paper.

122 See, for example, Companies Act 1993, s 15; Close Corporations Act 1984 (ZA), s 2(3); Wyoming Limited Liability Company Act, Wyo Stat § 17-15-113 (1977) and Uniform Limited Liability Company Act (1996), above n 3, ss 201 and 303.

123 For example, stated and par value shares. This does not include the solvency test.

124 See Law Commission Company Law Report, above n 1, paras 84 and 223-228. 
therefore does not consider such proposals would be appropriate for a new closely-held companies statute for New Zealand.

\section{Duties to creditors}

The final possibility for creditor protection is imposing directors' duties in favour of creditors. This is the approach of the current Companies Act, which imposes a number of different duties in favour of creditors. 125 First, the Companies Act imposes a duty on directors not to trade "recklessly" - that is, a director must not agree, cause or allow the business of a company to be carried on in a manner "likely to create a substantial risk of serious loss to the company's creditors". ${ }^{126}$ Second, there is a duty not to enter into obligations that cannot be performed. ${ }^{127}$ Third, there is a duty to keep accounting records. ${ }^{128}$ Fourth, in specific relation to payments to principals, there are two further different duties/tests - payments to a principal as a director must effectively be reasonable, ${ }^{129}$ while payments to a principal as a shareholder must satisfy the solvency test. ${ }^{130}$ Finally, the Companies Act includes something of a catch-all duty on directors (and certain others) not to act negligently or otherwise breach any duty or trust. ${ }^{131}$ Related to this catch-all duty, there is also a common law duty to creditors not to cause loss, at the least in the case of insolvency or potential insolvency of a company. ${ }^{132}$

The United States and South Africa similarly impose duties on principals of closely-held companies in favour of creditors. The United States approach varies between jurisdictions. The more robust view as to limitation of liability only holds a principal liable in a limited range of

125 Note that some duties are owed to the company, and some are owed to creditors directly. This is considered below - see below, Part V C $4 \quad$ Balancing mechanisms versus direct regulatory requirements.

126 Companies Act 1993, s 135.

127 Companies Act 1993, s 136.

128 Companies Act 1993, ss 194 and 300.

129 Companies Act 1993, ss 161(4) and 161(5).

130 Companies Act 1993, ss 4, 52, 53, 107 and 108. As to directors' liability, see Companies Act 1993, s 52(2), 56(2) and 108(2), as well as s 134. Note that the recipient of the payment may also be liable for any distributions received that the recipient knew were in contravention of the solvency test (see Companies Act 1993, ss 56(1) and 108(4)). For a closely-held company, such differentiation of liability is not particularly useful.

131 Companies Act 1993, s 301. Note that this is phrased as a discretionary remedy, rather than a duty.

132 Nicholson v Permakraft (NZ) Ltd [1985] 1 NZLR 242, 249-250 (CA) Cooke J. See also West Mercia Safetywear Ltd (in liq) v Dodd [1988] BCLC 250; [1988] BCC 30 (EWCA); Morrison's Company Law (NZ), above n 58, paras 24.8, Sealy "Directors' 'Wider' Responsibilities - Problems Conceptual, Practical and Procedural", above n 31, 178-179; Francis Dawson "Acting in the Best Interests of the Company - For Whom are Directors 'Trustees'?" (1984) 11 NZULR 68, 68-70 and Cooney Report, above n 31, paras 5.1 and following. 
circumstances: a principal is liable for company property and money; ${ }^{133}$ for capital he/she has agreed to, but has not yet, contributed; ${ }^{134}$ and for distributions received in breach of the solvency test. ${ }^{135}$ The slightly less robust view adopts generally the same approach, ${ }^{136}$ but with the addition of a general duty not to engage in knowing violations of the law, intentional misconduct, reckless conduct, or grossly negligent conduct. ${ }^{137}$ That is, a principal has a general duty of care to the standard of gross negligence not to cause loss. It is, however, important to note that this apparently robust approach is countered by the well-established United States "piercing the corporate veil" doctrine. Under this doctrine, it is possible to set aside limited liability protections in a range of circumstances, including fraud, undercapitalisation, the "alter ego" doctrine, and, in some circumstances, failure to observe the formalities of the corporate form. ${ }^{138}$

The South African approach is again broadly similar. Principals are liable for promised contributions ${ }^{139}$ and distributions made in breach of the solvency test. ${ }^{140}$ Like the less robust approach in the United States, South Africa also has general duty of care provisions. Unlike the United States, South Africa's statute provides for two standards of care: both ordinary negligence ${ }^{141}$

133 See, for example, Wyoming Limited Liability Company Act, Wyo Stat § 17-15-121(b) (1977).

134 See, for example, Wyoming Limited Liability Company Act, Wyo Stat § 17-15-121(a) (1977).

135 See, for example, Wyoming Limited Liability Company Act, Wyo Stat §§ 17-15-119 and 17-15-120 (1977). The solvency test used in the Wyoming Limited Liability Company Act is a simple test of assets exceeding liabilities - see Wyoming Limited Liability Company Act, Wyo Stat § 17-15-119 (1977).

136 See, for example, Uniform Limited Liability Company Act (1996), above n 3, ss 409(b)(1), 402 and 406 407. The solvency test used in the Uniform Limited Liability Company Act is a two-stage test of assets exceeding liabilities and ability to pay debts in the ordinary course of business - see s 406(a).

137 See, for example, Uniform Limited Liability Company Act (1996), ibid, s 409(c). See also s 303, comment.

138 See generally, Vandervoort "Piercing the Veil of Limited Liability Companies: The Need for a Better Standard", above n 70, 58-63. Note that failure to observe formalities has generally been questioned as a factor (see 59-61), and in some cases, statutorily abolished - see, for example, Uniform Limited Liability Company Act (1996), ibid, s 303(b).

139 Close Corporations Act 1984 (ZA), ss 24(5) and 63(b).

140 Close Corporations Act 1984 (ZA), s 51. South African adopts a broader meaning of distribution (any payment to a principal by reason only of his/her status as principal - that is, excluding only contracts for services) and a three part solvency test (balance sheet, ability to pay debts as they become due, and whether in fact the distribution will mean debts will not be able to be paid - see Close Corporations Act 1984 (ZA), s 51(1)).

141 Close Corporations Act 1984 (ZA), s 43. 
and gross negligence. ${ }^{142}$ Additionally, South Africa requires accounting records to be kept, although the direct penalty for breach is criminal, rather than civil. ${ }^{143}$

The approaches of the United States and South Africa, although somewhat simpler than New Zealand, are still complicated. Much of this complexity is due to the fact that company law seldom imposes direct regulatory requirements. Rather, most regulatory requirements are owed to "the company" in a type of balancing mechanism.

\section{Balancing mechanisms versus direct regulatory requirements}

In a company (particularly a widely-held company), there may be a number of competing interest groups, including directors, shareholders and creditors, and potentially subgroups of shareholders and creditors ("stakeholders"). There may be tensions between the interests of such stakeholders - for example, a shareholder's interest in the company maximising its dividends may be opposed to creditor's interests in the company maintaining sufficient assets to pay its debts.

Company law therefore attempts to provide a mechanism to resolve the competing interests of the assorted stakeholders in a company. Rather than owing separate and potentially conflicting duties to ensure the various groups of stakeholders' interests are maintained, the majority of directors' duties are instead owed to the company. ${ }^{144}$ The primary duty is to act in the best interests of the company. ${ }^{145}$ This mechanism effectively allows certain interests to trump other interests. So in the shareholder/creditor interests example above, it is in the interests of the company not to become insolvent, therefore it is not in the interests of the company to distribute all cash received to the shareholders as quickly as possible.

Taking the example of a one-person closely-held company, ${ }^{146}$ however, it is clear that there are no competing interests to "balance". The only major group of stakeholders in a one-person closelyheld company would be its creditors. Following this reasoning to its conclusion, there is no need to impose on the principal a duty to creditors via "the company" at all. Instead, it would be possible to simply impose a direct duty on the principal of a one-person company in favour of creditors. This is

142 Close Corporations Act 1984 (ZA), s 64.

143 Close Corporations Act 1984 (ZA), s 56.

144 See Companies Act 1993, s 169(3), and, for example, Close Corporations Act 1984 (ZA), s 43, and Uniform Limited Liability Company Act (1996), above n 3, s 409(c).

145 Companies Act 1993, s 131. See also Law Commission Company Law Report, above n 1, paras 184-196 and 504-509 and clause 101.

146 Considering a one-person company also forces greater focus on the specific considerations of the corporate form, without the diversions associated with multiple shareholders. The position of multiple shareholders is considered below - see below, Part VI D Multi-Principal Closely-Held Companies. 
similar to the current common law approach in New Zealand as expressed in Nicholson $v$ Permakraft. ${ }^{147}$

This would have the advantage of simplicity. The complexities and vagaries of the balancing exercise have been criticised. ${ }^{148}$ This approach would also avoid situations where wrongdoers indirectly benefit from actions taken against them. ${ }^{149}$ Further, it would obviate the need for morecomplicated enforcement mechanisms such as a derivative actions. ${ }^{150}$ Such mechanisms are arguably disadvantageous for shareholders, ${ }^{151}$ as they must effectively satisfy the court twice of the appropriateness of the action. ${ }^{152}$ This approach would also avoid the need for particular (and more complicated) provisions relating to shareholder ratification and the need to prevent after-the-event ratifications of actions to the detriment of creditors. ${ }^{153}$

\section{Standard of care}

This paper recommends imposing a duty of care on the principals of a closely-held company in respect of the company's creditors. The appropriate standard of care for that duty must be considered. Imposing liability too readily will discourage what may be justifiable business risks because of fear of individual liability; making it too difficult to hold delinquent principals liable will not uphold creditors' interests.

There are a number of possibilities for such a standard. New Zealand, ${ }^{154}$ the United States ${ }^{155}$ and South Africa ${ }^{156}$ all currently provide for a solvency test for some matters. This is effectively a

147 Nicholson v Permakraft, above n 132.

148 See, in particular, Sealy "Directors' 'Wider' Responsibilities - Problems Conceptual, Practical and Procedural", above n 31, 175.

149 For example, the situation where a director has breached a duty to a company and the company successfully sues him/her for that breach. If, however, the director were also a shareholder in that company, he/she would indirectly benefit anyway due to the increase in value of his/her shares.

150 See Companies Act 1993, Part IX, and in particulars ss 165 and 169. See also Law Commission Company Law Report, above n 1, para 318.

151 Although there are costs advantages - see Companies Act 1993, s 166.

152 Leave of the Court is required to bring a derivative action - see Companies Act 1993, s 165 and Vrij v Boyle [1995] 3 NZLR 763 (HC). See also Securities Markets Act 1988, s 18 and Colonial Mutual Life Assurance Society Ltd $v$ Wilson Neill Ltd [1994] 2 NZLR 152 (CA).

153 See McCullagh v Gellert, above n 24; Morrison's Company Law (NZ), above n 58, paras 25.42-25.44; Close Corporations Act 1984 (ZA), s 43(2); Wyoming Limited Liability Company Act, Wyo Stat § 17-15-121(c) (1977) and Uniform Limited Liability Company Act (1996), above n 3, s 103(b)(2)(ii).

154 Companies Act 1993, s 4.

155 For example, Wyoming Limited Liability Company Act, Wyo Stat §§ 17-15-119 and 17-15-120 (1977) and Uniform Limited Liability Company Act (1996), ibid, ss 406-407. See also above, n 135 and n 136. 
"strict" standard, in that it is either satisfied in the particular circumstances or it is not. Both the United States ${ }^{157}$ and South Africa ${ }^{158}$ use a gross negligence test for some matters; South Africa also uses ordinary negligence in some circumstances. ${ }^{159}$ New Zealand has an array of tests, ${ }^{160}$ the standard of which is not always clear. ${ }^{161}$

Into this already-confusing mix must be added the common law "business judgment rule". This rule reflects the courts' traditional reluctance to become involved in matters of "business judgment" and to not second guess particular decisions of directors. ${ }^{162}$ It is effectively a presumption of nonliability where the transaction is not self-interested, is undertaken on an informed basis, and is not irrational. ${ }^{163}$ A form of the business judgment rule is recognised in the Companies Act, ${ }^{164}$ although it does not appear to have been interpreted as such. ${ }^{165}$

Out of this multitude, one common theme is perhaps that greater scrutiny needs to be paid to self-interested transactions. Other than this, it is difficult to determine any general trends or any

156 Close Corporations Act 1984 (ZA), 51(1). See also above, n 140.

157 For example, Uniform Limited Liability Company Act (1996), above n 3, s 490(c). See also above, n 137.

158 Close Corporations Act 1984 (ZA), s 64. See also above, n 142.

159 Close Corporations Act 1984 (ZA), s 43. See also above, n 141.

160 See, for example, Companies Act 1993, ss 131-138 and 300-301, and Nicholson v Permakraft, above n 132.

161 See, for example, Companies Act 1993, s 135. Notwithstanding the title of the section being "reckless" trading, the section itself refers to "likely to create a substantial risk of serious loss" (emphasis added). See also Re Global Print Strategies Ltd (In Liquidation) (alt cit Mason v Lewis) (25 November 2004) HC AK M459-IM03, para 38 Salmon J (note that while this case was reversed on appeal, the observations on s 135 were not challenged - see Mason v Lewis, above n 17) and Fatupaito v Bates [2001] 3 NZLR 386; (2001) 9 NZCLC 262,583, paras 60-67 (HC) O'Regan J. Goddard goes further and describes some of the duties (Companies Act 1993, ss 135 and 136) as "extraordinary" - see Goddard "Company Law Reforms Lessons from the New Zealand Experience", above n 19, 159 and footnote 35.

162 See, for example, Re City Equitable Fire Assurance Co [1925] Ch 407 (CA).

163 See Corporations Act 2001 (Aus), s 180(2) and Aronson v Lewis (1984) 473 A 2d 805, 812 (Supreme Court of Delaware) Moore $\mathrm{J}$ for the Court. There are many articles relating to the business judgment rule - see, for example, L S Sealy "Reforming the Law on Directors' Duties" (1991) 12 Comp Law 175, 177; Len Sealy "Directors' Duties Revisited" (2001) 22 Comp Law 79, 79; David Tan "Delivering the Judgment on a Statutory Business Judgment Rule in Australia" 1995 AJCL LEXIS 39, in particular 4-12 and 17-24; Cooney Report, above n 31, paras 3.30-3.35; and England and Wales Law Commission and the Scottish Law Commission Company Directors: Regulating Conflicts of Interests and Formulating a Statement of Duties, above n 38, paras 5.21-5.25.

164 See Companies Act 1993, s 138, and Law Commission Company Law Report, above n 1, paras 520-522 and clause 107.

165 Compare, for example, the Court of Appeal judgment in Mason v Lewis, above n 17, in particular paras 7783 Judgment of the Court, with the High Court judgment in the same case (Re Global Print Strategies Ltd (In Liquidation), above n 161), in particular paras 41-42 and 67-68 Salmon J. 
particular standard of international best practice. While it is clearly necessary to strike an adequate balance between protecting creditors' interests and not unduly fettering business discretion, there will always be some dispute about whether the correct balance has been stuck.

\section{Proposed duty of care}

With the factors considered in the previous sections in mind, as well as the general principle of flexibility, ${ }^{166}$ this paper proposes a general duty not to conduct the business of a closely-held company in such a way that causes loss to creditors. This duty would be imposed on principals directly in favour of creditors, without resort to "the company", as is outlined in Nicholson $v$ Permakraft. ${ }^{167}$ That case phrased the duty as only arising in the event of insolvency, however. ${ }^{168}$ It seems that this could be approached more simply as a duty to refrain from prejudicing the interests of creditors generally. This is effectively a duty not to become insolvent. This paper therefore recommends that the new closely-held companies statute provide that:

Draft Clause: Duties of Principals to Creditors

(1) The Principal(s) of a Closely-Held Company must not conduct the business of the Closely-Held

Company in such a way that causes loss to creditors of the Closely-Held Company.

This clearly favours creditors too much. It is therefore necessary to introduce a range of exceptions/defences for principals. Broadly, this paper recommends that there should be two standards of care: one for non-interested transactions and one for self-interested transactions. Selfinterested transactions require much greater scrutiny and therefore a higher standard of care. This paper therefore recommends that the new statute provide:

(2) A Principal that breaches the duty in subsection (1) is liable to creditor(s) that suffer loss due to the breach, unless:

(a) The Principal, in causing the Closely-Held Company to undertake the actions that are alleged to have cause the breach: ${ }^{169}$

(i) Did not have a personal interest in the actions, or the outcome of the actions;

(ii) Acted in an informed manner; and

(iii) Had a rational belief that the actions would not cause loss to creditors; or

166 See above, Part IV D Flexibility.

167 Nicholson v Permakraft, above n 132.

168 Ibid, 249-250 Cooke J.

169 See, for example, Corporations Act 2001 (Aus), s 180(2). 
(b) The actions that are alleged to have caused the breach would have been undertaken by a reasonably prudent business person acting as a Principal of the Closely-Held Company.

(3) For the purposes of subsection (2)(a)(iii), a belief is rational unless it is a belief such that no reasonable person in the position of the Principal could hold it. ${ }^{170}$

This approach would utilise a version of the business judgment rule for non-interested transactions. So long as a principal is not interested in the transaction, and makes the decision on an informed and rational basis, it is not open to challenge. This should empower principals with sufficient security from liability to encourage business decisions.

This paper proposes a reasonableness standard for self-interested transactions. This effectively extends the current New Zealand position for non-distribution payments to principals ${ }^{171}$ to all selfinterested transactions, including dividends. This is more flexible than the traditional solvency test. The use of a "reasonably prudent business person acting as a principal of the closely-held company" acknowledges that the nature of business undertaken by closely-held companies will vary from company to company. ${ }^{172}$

The courts have traditionally been reluctant to interfere with business decisions or formulate a "reasonable businessman" standard of care. ${ }^{173}$ In practice, however, such a standard has been developing in relation to prohibitions of delinquent directors. ${ }^{174}$ There does not seem to be any reason why such a standard should not extend to liability as well as potential prohibition. Punishment through prohibition is likely to be of little comfort to out-of-pocket creditors. Reasonableness (in varying forms) is also used by South Africa and the United States. ${ }^{175}$

Out of concern that reasonableness may be uncertain for some risk-averse principals, it may be appropriate to introduce a safe-harbour provision for self-interested transactions:

170 See, for example, Corporations Act 2001 (Aus), s 180(2). This is akin to a public law/Wednesbury reasonableness test - see Associated Provincial Picture Houses Ltd $v$ Wednesbury Corporation [1948] 1 KB 223 (EWCA).

171 Companies Act 1993, s 161.

172 See also above, Part IV D Flexibility.

173 See, for example, Re City Equitable Fire Assurance Co, above n 162.

174 See Companies Act 1993, s 385, National Enforcement Unit Banned Directors and Managers / Director Prohibitions (Ministry of Economic Development, Wellington, 2006) www.enforcement.med.govt.nz (accessed 6 September 2006); Company Directors Disqualification Act 1986 (UK); Insolvency Service (United Kingdom) Director Disqualification \& Restrictions (Insolvency Service, London, 2006) http://insolvency.gov.uk (accessed 23 September 2006) and Len Sealy "Directors Duties in the New Millennium" (2000) 21 Comp Law 64, 64 and Sealy "Directors' Duties Revisited", above n 163, 79-80.

175 See above, Part V C 3 Duties to creditors and Part V C $55 \quad$ Standard of care. 
(4) For the purposes of subsection (2)(b), the actions that are alleged to have caused the breach shall be deemed to be reasonable if, at the time the actions are undertaken: ${ }^{176}$

(a) The Closely-Held Company is able to pay its debts as they become due in the normal course of business; and

(b) The value of the Closely-Held Company's assets is greater than the value of its liabilities, including contingent liabilities.

This approach would deem any transaction that satisfied a solvency test to be reasonable. Principals that were willing to undertake the necessary steps to determine whether the solvency test is satisfied (probably by taking accounting advice) would be safe from liability to creditors. This would be an optional safe-harbour.

\section{Practical considerations: enforcement}

Enforcement of duties to creditors is a particular issue. Creditors may be reluctant to pursue actions against delinquent principals due to the time and cost involved. In particular, creditors are likely to be reluctant to "throw good money after bad" pursuing principals. This may be compounded if principals have adopted some of the asset protection mechanisms described in the preceding section.

One method of improving enforcement is through mandatory liability insurance for principals. Principals could be required to insure against liability to creditors under the duties proposed above. This would ensure that creditors would be able to recover, even if principals have employed some measure of asset protection. Moreover, it could lower the costs of enforcement. If it was more economical for insurers to pay out valid claims, court action would not be necessary. Finally, and perhaps most importantly, if insurance was mandatory for all principals, then principals with a history of dereliction of duty to creditors would either pay much higher premiums or perhaps even be entirely uninsurable. The market would itself reduce the incidence of delinquent principals.

Such a proposal would clearly be contingent on the availability of such insurance. In drafting this paper, a number of insurers offering "director and officer" insurance were contacted directly. While such insurance does exist for smaller companies, it is tailored more towards larger companies. Moreover, several of the insurers only provide insurance to directors/officers/principals with an established history of compliance with legal obligations. At least one other insurer's

176 See, for example, Companies Act 1993, s 4, and Law Commission Company Law Report, above n 1, paras 330-333 and clause 3(3) (note that the Law Commission's formulation is preferred as it provides greater flexibility). See also, for example, Close Corporations Act 1984 (ZA), 51; Wyoming Limited Liability Company Act, Wyo Stat § 17-15-119 (1977) and Uniform Limited Liability Company Act (1996), above n 3, s 406(a). 
coverage for non-established principals excludes claims if the company becomes insolvent. ${ }^{177}$ New principals may therefore find it difficult to arrange the required insurance. Introducing a mandatory insurance requirement may create barriers for people to establish new closely-held companies.

If the insurers were not willing or able to establish the requisite insurance market, an alternative would be to establish an "assetless company fund", as was recommended by the Law Commission, ${ }^{178}$ or to increase the scope of the existing Liquidation Surplus Account. ${ }^{179}$ This would effectively provide a legal aid fund to assist creditors in pursuing claims against delinquent principals. This would ensure that delinquent principals could be held to account, even where it may not otherwise be economically justifiable to pursue a claim. Draft clause(s) would depend on which approach is adopted.

\section{Multi-Principal Closely-Held Companies}

1 Relations of principals to each other: default rules

Multi-principal closely-held companies introduce some complications. The closely-held companies statute will need to provide certain rules relating to the relations of principals among themselves. Obviously, single-principal closely-held companies will be able to disregard such rules. These should be "default" rules, able to be modified by agreement. ${ }^{180}$ Default rules make matters as simple as possible for basic closely-held companies, while making allowance for the particular needs of individual companies if appropriate. ${ }^{181}$

\section{Rights of principals}

A consideration of comparative precedent reveals some fairly common themes for these default rules. First, they consider the rights of principals. These include the straightforward rights to be involved in the management of the closely-held company and to access information:

177 Interview with B, anonymous insurer (the author, by telephone, 28 July 2006); correspondence with C, anonymous insurer (the author, by email, 19 July 2006); correspondence with D, anonymous insurer (the author, by email, 19 July 2006); and correspondence with Insurance Council (the author, by email, 18 July 2006). As the information provided could be commercially sensitive, an undertaking not to disclose the detailed information was provided.

178 See Law Commission Company Law Report, above n 1, paras 647 and 710 and cls 243-249.

179 See Companies Act 1993, s 316. See also Insolvency and Trustee Service "Liquidation Surplus Account" (December 2002) 13 Insolvency Quarterly Newsletter Wellington 5 www.insolvency.govt.nz (accessed 23 September 2006).

180 Modification of default rules is considered in the next section of this paper - see below, Part VI A 5 Modification of default rules.

181 See also above, Part IV D $\quad$ Flexibility, and below, Part VI A $5 \quad$ Modification of default rules. 
Draft Clause: Rights of Principals

The Principal(s) of a Closely-Held Company have the right to:

(a) Be involved in the management of the Closely-Held Company; ${ }^{182}$ and

(b) Access all information relating to the affairs of the Closely-Held Company. ${ }^{183}$

\section{Shares, interests and distributions}

Second, it is necessary to make provision for dividing the interests in a closely-held company among principals. Again, the comparative precedents adopt a common approach. Contrary to company law, none of the comparative precedents provide for "shares". Only the South African statute makes express reference, by providing that interests are to be determined by way of percentage. ${ }^{184}$ The other statutes are silent, allowing principals to make their own arrangements if appropriate. ${ }^{185}$ Without express agreement to the contrary by the principals, however, the default position is for an even distribution of interests. This is a simple and seemingly effective approach, particularly for basic equal-share companies that will not vary the pro rata distribution of interests. Given a general duty to creditors has already been provided elsewhere, ${ }^{186}$ it is possible to stay silent as to interests, and provide a very simple approach to making distributions, for example:

Draft Clause: Distributions

A Closely-Held Company must make equal distributions among all its Principals. ${ }^{187}$

\section{Duties of principals to each other}

Next, and again similar to the rights described above, there are some common themes in terms of duties of principals. These include the straightforward accounting for property, disclosure of information, non-competition, and a general duty to comply with the requirements of the statute and operating agreement. A draft clause may read:

182 See, for example, Close Corporations Act 1984 (ZA), s 46(a); Wyoming Limited Liability Company Act, Wyo Stat § 17-15-116 (1977); Uniform Limited Liability Company Act (1996), above n 3, s 404(a) and Partnerships Act 1908, s 27(e).

183 See, for example, Uniform Limited Liability Company Act (1996), ibid, s 408, and Partnerships Act 1908, s 31.

184 See Close Corporations Act 1984 (ZA), s 30(1).

185 See, for example Close Corporations Act 1984 (ZA), s 12(e), and Partnerships Act 1908, s 27(a). See also below, Part VI A $5 \quad$ Modification of default rules.

186 See above, Part V C 66 Proposed duty of care.

187 See, for example, Close Corporations Act 1984 (ZA), s 46(f); Wyoming Limited Liability Company Act, Wyo Stat § 17-15-119 (1977) and Uniform Limited Liability Company Act (1996), above n 3, s 405(a). 
Draft Clause: Duties of Principals to Each Other

(1) The Principal(s) of a Closely-Held Company must:

(a) Account to the other Principal(s) of the Closely-Held Company (if any) for any property, profit or other benefit derived in the course of conducting the Closely-Held Company's business; ${ }^{188}$

(b) Keep the other Principal(s) of the Closely-Held Company (if any) informed of any matters that may reasonably affect the business of the Closely-Held Company or the position of the other Principal(s); ${ }^{189}$

(c) Not compete in business with the Closely-Held Company or otherwise utilise the information or business opportunities of the Closely-Held Company for private gain; ${ }^{190}$ and

(d) Not breach, or conduct the business of the Closely-Held Company in such a way that the Closely-Held Company breaches, the Operating Agreement of the Closely-Held Company or this Act.

(2) A Principal that breaches the duty in subsection (1) is liable to the Principal(s) of that CloselyHeld Company not party to the breach that suffer loss due to the breach.

\section{Entry and exit}

It is also necessary to consider entry and exit rights of principals. While the comparative precedent is largely uniform in requiring the unanimous consent of existing principals to introduce a new principal, there is no consistent approach to exit rights of principals. The United States ${ }^{191}$ and New Zealand partnership law, ${ }^{192}$ for example, provides by default that principals have the right to exit at any time. South Africa adopts a more traditional company law approach, and does not allow exit at will. 193

188 See, for example, Close Corporations Act 1984 (ZA), s 42(2)(b)(i); Uniform Limited Liability Company Act (1996), above n 3, s 409(b)(1) and Partnerships Act 1908, ss 23, 24 and 32.

189 See, for example, Partnerships Act 1908, s 31; Close Corporations Act 1984 (ZA), s 42(2)(b)(ii) and Uniform Limited Liability Company Act (1996), ibid, s 408.

190 See, for example, Close Corporations Act 1984 (ZA), s 42(2)(b)(iii); Uniform Limited Liability Company Act (1996), ibid, s 409(b)(3) and Partnerships Act 1908, ss 32-33.

191 See, for example, Wyoming Limited Liability Company Act, Wyo Stat § 17-15-120 (1977); Uniform Limited Liability Company Act (1996), ibid, s 602(a). Note however this may be due to the United States' tax position - see Uniform Limited Liability Company Act (1996), prefatory note, 1.

192 Partnerships Act 1908, s 29.

193 See Close Corporations Act 1984 (ZA), ss 33-40. 
Allowing withdrawal at will would limit the potential for disputes to arise, as an aggrieved principal could withdraw at any time. On the other hand, it may also lead to business uncertainty if business partners can at any time go their own way, taking their capital with them. ${ }^{194}$ This business uncertainty may be able to be managed through appropriate notice and transitional requirements in the statute.

This paper is inclined towards the United States exit-at-will approach due to its ability to limit disputes, but this is a finely balanced matter. A draft clause may read:

Draft Clause: Entry and Exit of Principals

(1) No person may become a Principal of a Closely-Held Company without the unanimous consent of the other Principal(s). ${ }^{195}$

(2) The Principal(s) of a Closely-Held Company have the right to exit from the Closely-Held Company at any time. ${ }^{196}$

It would, however, also be necessary to include some ancillary provisions relating to matters such as the nature of an interest that is transferred contrary to subsection (1), ${ }^{197}$ the process and timeframes for exit under subsection (2), ${ }^{198}$ and for liability before and after exit or entry. ${ }^{199}$ These are detailed matters outside the scope of this paper, however.

\section{Modification of default rules}

As discussed, the above should be default rules to make matters as simple as possible for basic closely-held companies. ${ }^{200}$ Also as discussed, it is necessary to make allowances for the particular needs of individual closely-held companies. Most importantly, there should be sufficient flexibility to allow principals to arrange internal matters to suit their particular circumstances, including modifying the default rules.

194 See also Law Commission Company Law Report, above n 1, paras 206-207.

195 See, for example, Close Corporations Act 1984 (ZA), s 33; Wyoming Limited Liability Company Act, Wyo Stat $\S \S 17-15-122$ and 17-15-144(b) (1977) and Partnerships Act 1908, s 27(g).

196 See, for example, Wyoming Limited Liability Company Act, Wyo Stat § 17-15-120 (1977); Uniform Limited Liability Company Act (1996), above n 3, s 602(a) and Partnerships Act 1908, s 29.

197 See, for example, Uniform Limited Liability Company Act (1996), ibid, s 502 and Partnerships Act 1908, s 34(1).

198 See, for example, Uniform Limited Liability Company Act (1996), ibid, ss 601(1) and s 603(a)(1).

199 See, for example, Partnerships Act 1908, ss 20 and 39(3).

200 See above, Part IV D Flexibility. 
The Companies Act anticipates this through the use of company constitutions, ${ }^{201}$ but only to a degree. $^{202}$ The United States ${ }^{203}$ and South African ${ }^{204}$ closely-held companies statutes, and even New Zealand partnership law, ${ }^{205}$ expressly provide for much greater flexibility. The default rules relating to relationships of principals among themselves, as well as the powers and functions of principals, are expressly subject to modification by agreement. This greater flexibility seems appropriate for the new closely-held companies statute. This paper therefore proposes the following clause:

Draft Clause: Operating Agreement

(1) A Closely-Held Company may have an Operating Agreement to: ${ }^{206}$

(a) Regulate the operation of the business of that Closely-Held Company; and

(b) Govern the relations among the Principal(s) of that Closely-Held Company.

(2) The Principal(s) of a Closely-Held having an Operating Agreement must act in accordance with the provisions of that Operating Agreement. ${ }^{207}$

Adopting an operating agreement would require the unanimous agreement of principals, as an operating agreement is binding on all principals. Unanimous agreement would also be required to amend or revoke an operating agreement. An additional consequence of this is that it is effectively possible to act outside the operating agreement if all principals agree:

(3) An Operating Agreement may be adopted, replaced, amended or revoked at any time by the unanimous agreement of the Principal(s) of the Closely-Held Company. ${ }^{208}$

It is also necessary to consider whether this flexibility to arrange internal affairs should be unrestricted, or have certain limitations placed on it. Some matters should clearly be capable of

201 See Companies Act 1993, Part V.

202 See, in particular, Companies Act 1993, s 31(1).

203 See, for example, Wyoming Limited Liability Company Act, Wyo Stat § 17-15-107(a)(xi) (1977) and Uniform Limited Liability Company Act (1996), above n 3, s 103.

204 See Close Corporations Act 1984 (ZA), ss 44 and 46.

205 See Partnerships Act 1908, s 22.

206 See, for example, Close Corporations Act 1984 (ZA), s 44; Wyoming Limited Liability Company Act, Wyo Stat § 17-15-107(a)(xi) (1977) and Uniform Limited Liability Company Act (1996), above n 3, s 103.

207 See, for example, Close Corporations Act 1984 (ZA), s 44(4) and Uniform Limited Liability Company Act (1996), ibid, s 409(d).

208 See, for example, Close Corporations Act 1984 (ZA), ss 44(1) and 44(6) and Uniform Limited Liability Company Act (1996), ibid, s 103(a). 
being modified by agreement. Matters such as the proportion of distributions among principals will be modified almost as a matter of course. Other matters, such as entry and exit rights, should similarly be able to be modified to suit individual circumstances. Even the assorted directors' duties to each other may be dispensed with (or at least breaches ratified by unanimous agreement) in appropriate circumstances. All the comparative precedents allow for modification of these matters. ${ }^{209}$

The rights of principals to access information and be involved in the management of the closelyheld company may be considered more important. The general scheme of the proposed closely-held companies statute is that substantial regulatory requirements are not required. But this is based on the premise that involvement in management obviates the need for regulatory requirements. Limiting a principal's involvement in management and/or access to information is more akin to a company-style approach of separate directors and shareholders. As discussed, this is a situation that may be abused, hence the need for regulatory requirements. It may therefore not be appropriate to allow principals to alter these rights by agreement.

Although no comparative precedents prohibit the alteration of these rights by agreement, some provide that they may not be unreasonably restricted. ${ }^{210}$ This strikes a balance between respecting the ability of principals to decide for themselves ${ }^{211}$ and acknowledging the accountability concerns if someone is a principal of a closely-held company without any access to information or involvement in management. The majority of the comparative precedent, however, allows even the information and management rights to be modified, presumably on the basis of allowing people to decide for themselves. The only limitation is that such modifications cannot be "inconsistent with the law". ${ }^{212}$

This paper prefers the former view for the reasons outlined, notwithstanding the fact that the majority of comparative precedent favours the latter. These matters are so fundamental that they should not be subject to exclusion:

(4) The provisions of an Operating Agreement may:

209 See Close Corporations Act 1984 (ZA), ss 44 and 46; Wyoming Limited Liability Company Act, Wyo Stat $\S 17-15-107$ (1977); Uniform Limited Liability Company Act (1996), ibid, s 103 and Partnerships Act 1908, ss 22 and 27.

210 See, for example, Uniform Limited Liability Company Act (1996), ibid, s 103(b).

211 Goddard "Company Law Reforms - Lessons from the New Zealand Experience", above n 19, 166.

212 See, for example, Close Corporations Act 1984 (ZA), ss 44(1)(b) and 46 and Wyoming Limited Liability Company Act, Wyo Stat § 17-15-107(a)(xi) (1977). 
(a) Modify any of the provisions of sections [Distributions], [Duties of Principals to Each Other], and [Entry and Exit of Principals] without restriction; ${ }^{213}$ and

(b) Modify any of the provisions of section [Rights of Principals], but only where it is reasonable to do so. ${ }^{214}$

\section{Creditors and balancing mechanisms}

This paper proposes imposing a duty on principals of closely-held companies in favour of creditors. The discussion of these duties above ${ }^{215}$ used the example of one-principal closely-held companies to avoid the potential complications that may arise with multi-person companies. ${ }^{216}$ There does not seem to be any reason why matters should become overly-complicated simply because multiple principals become involved in a closely-held company. There is no difference between several principals and one principal owing the duties to creditors as outlined in this paper.

The balancing mechanisms associated with competing duties are nominally more complicated. As discussed, company law traditional uses a duty to "the company" to resolve disputes. ${ }^{217}$ This does not seem necessary, however, even in the case of multiple principals. It is difficult to envisage a situation where the very basic duty not to prejudice the position of creditors will conflict with any of the duties to other principals. In the event that it does, this paper proposes a hierarchy of duties, ${ }^{218}$ with the duty to creditors taking precedence over the duties to other principals (so long as there is a causative link between the wrongful act and the loss to creditors). For the reasons outlined above, this seems a far simpler method than utilising the balancing mechanism. ${ }^{219}$

\section{B Remedies}

1 General: criminal versus civil remedies

The remedies for any breach of the duties to creditors and other principals also need to be considered. There are two broad options for remedies: criminal and civil remedies.

213 See, for example, Close Corporations Act 1984 (ZA), ss 44 and 46; Wyoming Limited Liability Company Act, Wyo Stat § 17-15-107 (1977); Uniform Limited Liability Company Act (1996), above n 3, s 103 and Partnerships Act 1908, ss 22 and 27.

214 See, for example, Uniform Limited Liability Company Act (1996), ibid, s 103(b).

215 See above, Part V C $4 \quad$ Balancing mechanisms versus direct regulatory requirements.

216 See above, n 146.

217 See above, Part V C $4 \quad$ Balancing mechanisms versus direct regulatory requirements.

218 See also Law Commission Company Law Report, above n 1, paras 194-195.

219 See above, Part V C 4 Balancing mechanisms versus direct regulatory requirements. 
The Companies Act imposes a range of criminal sanctions for breach of its assorted regulatory requirements. ${ }^{220}$ It is not clear that this is the most effective approach for enforcement. Prosecutorial discretion means that many of the more minor offences will never be prosecuted, ${ }^{221}$ particularly where no-one suffers any harm or loss. Moreover, the criminal law has a higher burden of proof, is slow, and has more restrictive rules of evidence. This is likely to be aggravated by the complexities of both company law and the modern commercial environment. ${ }^{222}$ The criminal law has therefore been described as a "blunt and largely ineffective instrument for ensuring that technical or administrative duties are complied with". ${ }^{223}$

South Africa, for example, has made a conscious choice to "decriminalise" many of the breaches of the Close Corporations Act. ${ }^{224}$ The primary remedy for any breach of the law is to impose personal civil liability. The basic approach is that a person who does not comply with the regulatory requirements of the Close Corporations Act forfeits the privileges associated with it - in particular, a person in breach effectively loses the protections of limited liability by incurring personal liability. ${ }^{225}$ Civil liability also has the effect of greater emphasis on self-enforcement. This means that enforcement will only be pursued where someone has suffered actual harm. ${ }^{226}$ This approach seems appropriate. This paper recommends that only civil remedies be imposed for breaches of duties. It may be necessary to impose criminal remedies for fraudulent behaviour, ${ }^{227}$ but this would be an exception to the general approach.

\section{Specific remedies}

In terms of specific civil remedies, given the nature of creditors' interests, any civil remedy for creditors will almost inevitably be in the form of damages. For breach of duties to other principals, an account of profits will frequently arise as the most appropriate remedy, as well as damages. Both of these are well-established remedies.

220 See Companies Act 1993, Part XXI.

221 The most high-profile incident is perhaps that involving David Parker and unanimous resolutions not to appoint an auditor - see Ian Wishart "Attorney-General Caught Filing False Documents" (20 March 2006) Investigate Magazine, New Zealand www.investigatemagazine.com (accessed 6 August 2006).

222 See S Du Toit and J J Henning "South Africa - Corporate Law Reform and the Empowerment of the Victims of Economic Crime" (1999) 20 Comp Law 277, 281.

223 Ibid, 283. See also the similar recommendations of the Cooney Report, above n 31, paras 13.10-13.15.

224 Du Toit and Henning, ibid, 280-284. See also Cooney Report, ibid, paras 13.10-13.12.

225 Du Toit and Henning, ibid, 283.

226 Du Toit and Henning, ibid, 283. This approach was also recommended for New Zealand by the Law Commission - see Law Commission Company Law Report, above n 1, paras 318, 564, 565 and 585.

227 For example, filing false documents or general use of the corporate form to defraud - see Companies Act 1993, ss 377, 379 and 380. 
One additional remedy that may be appropriate, however, is giving the court the power to (with the consent of the other principals) expel a principal from the closely-held company when they have breached their duties. Such a remedy is provided in South Africa. ${ }^{228}$ As for the right to exit a closely-held company, ${ }^{229}$ the most effective way to resolve a dispute may be to require quarrelling principals to go their separate ways.

These remedies would be available to the court, notwithstanding anything to the contrary in the operating agreement of the closely-held company (in particular, relating to the exit of principals). While the operating agreement can alter what amounts to a breach, once that breach is established, it should not be able to limit the court's available range of remedies. Limiting the available remedies may impair the court's ability to adequately address an actual breach and ensure justice in the individual case.

This paper therefore proposes the following be implemented:

Draft Clause: Remedies

(1) Despite anything in the Operating Agreement, where a Principal is liable under section [Duties of Principals to Creditors] or [Duties of Principals to Each Other], the Court may, to the extent that it is just and reasonable, order that the Principal: 230

(a) Pay damages to the person that has suffered loss due to the breach;

(b) Pay a sum up to the amount of personal profit made or loss avoided by that Principal to the person that has suffered loss due to the breach; and/or

(c) Be expelled from the Closely-Held Company. ${ }^{231}$

(2) The Court may make an order under subsection (1)(c) only with the consent of the other Principal(s) of the Closely-Held Company.

It would also be necessary to provide for ancillary matters related to an expulsion order, including the appropriate payout (if any) for the expelled partner, the timeframe for such payout, and liability before and after expulsion. ${ }^{232}$ The detail of these provisions is outside the scope of this paper.

228 See Close Corporations Act 1984 (ZA), s 36.

229 See above, Part VI A $4 \quad$ Entry and exit.

230 See, for example, Close Corporations Act 1984 (ZA), s 42(3) and Uniform Limited Liability Company Act (1996), above n 3, ss 409-410.

231 See Close Corporations Act 1984 (ZA), s 36.

232 These provisions will be similar to those for the exit of principals - see above, Part VI A 4 Entry and exit. 


\section{Transacting Business}

It is necessary to provide, for the avoidance of doubt, that closely-held companies have full legal capacity to transact business. The alternative, the ultra vires doctrine, is not appropriate in the New Zealand environment. ${ }^{233}$ This also caters to the potentially informal manner of conducting business by closely-held companies, by allowing closely-held companies to undertake all actions that the principals themselves are able to do:

Draft Clause: Capacity of Closely-Held Companies

A Closely-Held Company has all the rights, powers and legal capacity of a natural person. ${ }^{234}$

It is also necessary to consider how closely-held companies go about practically transacting business. Obviously, legal persons such as companies cannot act for themselves. The Companies Act, for example, generally empowers the board of a company to manage it, ${ }^{235}$ with agents used in order to transact business on a day-to-day basis. Theoretically at least, board authorisation is necessary to appoint a person an agent of a company. The technicalities of agency law are, however, probably beyond the standard closely-held company. As discussed in the empirical findings of this paper, the majority of a closely-held company's business will be transacted by the principals themselves. ${ }^{236}$

Again the comparative precedent provides a more appropriate approach for closely-held companies. The default rule is that all principals are deemed to be the agents of the company. This is a simple approach that is particularly suitable for closely-held companies:

Draft Clause: Transacting Business

(1) All Principal(s) of the Closely-Held Company are its agents for the purpose of its business. ${ }^{237}$

233 See Law Commission Company Law Report, above n 1, paras 95 and 342-348.

234 See, for example, Companies Act 1993, ss 15-17; Law Commission Company Law Report draft bill, clauses 7-8; Incorporated Societies Act 1908, s 10; Close Corporations Act 1984 (ZA), s2(2); Wyoming Limited Liability Company Act, Wyo Stat § 17-15-104 (1977) and Uniform Limited Liability Company Act (1996), above n 3, s 112(b).

235 Companies Act 1993, s 128.

236 See above, Part II A $11 \quad$ Synonymity. Note in particular that some 63 per cent of businesses have no employees at all - see above, n 16.

237 See, for example, Close Corporations Act 1984 (ZA), s 54; Wyoming Limited Liability Company Act, Wyo Stat § 17-15-117 (1977); Uniform Limited Liability Company Act (1996), above n 3, s 301 and Partnerships Act 1908, ss 8 and 9. 
New Zealand, however, has a particularly strong focus on form-over-substance in corporate law. ${ }^{238}$ Notwithstanding the generality of proposed subsection (1), it may be appropriate to provide a safe-harbour provision for closely-held companies:

(2) Any act by a Principal of a Closely-Held Company who uses the expression "[NAME OF PRINCIPAL], Principal, for [NAME OF CLOSELY-HELD COMPANY]" in doing the act is deemed to be the act of that Closely-Held Company.

This would deem any transaction using the particular expression to be a transaction of the closely-held company. This safe-harbour would provide additional guidance for principals of closely-held companies, and ensure that potential liability "traps" do not arise through ignorance or oversight of the law.

\section{Accounting Records and Other Obligations}

One obligation often set out in company law relates to accounting or financial reporting obligations. Such requirements can be particularly burdensome and without apparent benefit for closely-held companies. ${ }^{239}$ Any benefits that may be derived from such financial records can equally be derived from other statutory reporting obligations - in particular, annual tax returns. ${ }^{240} \mathrm{~A}$ tax return is equally able to achieve any goals such as assessing the performance of the business in the previous financial year, imposing business disciplines, or encouraging good decision making. This approach is adopted in other jurisdictions. ${ }^{241}$ Any other financial records that are practically necessary or useful (for example, in the context of considering the solvency test) will be prepared or commissioned by the closely-held company as needed or desired, not by regulatory compulsion.

There does not seem to be any need to set out any other obligations in the closely-held companies statute, other than some administrative requirements relating to registration and winding up. In relation to the latter, it is probably most appropriate to simply incorporate by reference the existing provisions of the Companies Act. This is a more complicated and technical area of law that is normally conducted by specialists, not by closely-held companies in their day-to-day activities. Additional complexity can therefore be justified. ${ }^{242}$

238 See, for example, Trevor Ivory Ltd v Anderson [1992] 2 NZLR 517 (CA) and Ede (trading as Electro Sheetmetals Ltd) v J A Russell Ltd (2001) 9 NZCLC 262,539 (HC).

239 See above, Part V C Creditors, Limited Liability and Regulatory Requirements, in particular n 36 and following.

240 Tax Administration Act 1994, s 33. In New Zealand at least, there is no obligation to file financial reports publicly for the majority of companies. The private nature of tax returns therefore does not matter.

241 There are no reporting requirements in either the Wyoming Limited Liability Company Act, Wyo Stat title 17 chapter 15 (1977) or the Uniform Limited Liability Company Act (1996).

242 Goddard "Company Law Reforms - Lessons from the New Zealand Experience", above n 19, 163. 


\section{E Formalities}

Finally, in light of the informality of closely-held companies, ${ }^{243}$ it may be appropriate to provide that even matters required under the statute do not have to comply with any particular level of formality (other than perhaps matters which must be sent to the Registrar of Closely-Held Companies, such as applications to incorporate a closely-held company):

Draft Clause: Formalities

Every matter contemplated by this Act may be done informally (including, without limitation, not in writing). ${ }^{244}$

\section{CONCLUSION}

This paper has attempted to show how the Companies Act is inadequate for closely-held companies in New Zealand. The essential problem of the Companies Act is that the regulatory requirements imposed on directors to ensure accountability to shareholders do not have any benefit where the directors of a company are also its shareholders. With no benefit, the costs arising from such regulatory requirements are therefore unjustified. This problem is effectively acknowledged in the Companies Act through the assorted concessions to closely-held companies. These concessions have their own problems, however, particularly in terms of compliance costs.

This paper has therefore proposed enacting a new statute designed to meet the needs of closelyheld companies. It has argued that this statute should be in addition to the existing Companies Act; it is not possible for one statute to cater to the needs of both widely- and closely-held companies. This new statute should be based on principles of accessibility and flexibility. From these general principles and a comparison of international precedent, the paper has set out some key features that are considered appropriate for a closely-held companies statute in New Zealand. While these proposals share many common origins with the Companies Act 1993, the paper has attempted to remove many of the undesirable aspects of that statute for closely-held companies.

This net result of this paper's proposals is a simple, flexible set of requirements suitable for closely-held companies in New Zealand, without onerous or unjustified compliance requirements. The paper argues that such a statute should be implemented to meet the needs of closely-held companies in New Zealand.

243 See above, Part 2 Informality.

244 See, for example, Uniform Limited Liability Company Act (1996), above n 3, s 103(a). 
